University of Rhode Island

DigitalCommons@URI

The Rhode Island Current Conditions Index

Economics

2-2012

\title{
Rhode Island Current Conditions Index - February 2012
}

Leonard Lardaro

University of Rhode Island, lardaro@uri.edu

Follow this and additional works at: https://digitalcommons.uri.edu/ricci

Part of the Econometrics Commons

Terms of Use

All rights reserved under copyright.

\section{Recommended Citation}

Lardaro, Leonard, "Rhode Island Current Conditions Index - February 2012" (2012). The Rhode Island Current Conditions Index. Paper 25.

https://digitalcommons.uri.edu/ricci/25

This Article is brought to you for free and open access by the Economics at DigitalCommons@URI. It has been accepted for inclusion in The Rhode Island Current Conditions Index by an authorized administrator of DigitalCommons@URI.For more information, please contact digitalcommons-group@uri.edu. 


\title{
CURRENT CONDITIONS I NDEX LEONARD LARDARO, URI
}

\author{
Available Online: http:/ / www.llardaro.com/ current.htm (NEW URL) \\ Blog: http:/ / rieconomy.blogspot.com
}

VOL $X I X$ NUMBER 3 FEB 2012
As we move to February, it is no longer clear whether the Rhode Island is still in a recovery or whether it has moved into the earliest stages of a dreaded double-dip recession. Payroll employment has now declined for seven consecutive months on a year-over-year basis (note: there was a negligible rise for one of those months). For many, this alone would be a sufficient basis upon which to make the recession call. However, I am not yet ready to make that call. Please don't construe this as indicating that I believe things here are going well. Rhode Island's labor market is in abysmal shape - just about everything is moving in the wrong direction. Let me briefly outline why I don't think Rhode Island has entered into recession - yet.

The payroll employment declines, while persistent, are not all that large in magnitude. They have largely been around 0.2 percent. Second, Retail Sales continues to show a great deal of momentum, rising in February, for example, by 6.3 percent compared to a year ago. Part of this is no doubt related to the skilled Rhode Islanders we rent out to neighboring states who bring their income home with them. But Retail Sales momentum clearly does have "legs" at present. We are also seeing continued strength in manufacturing. Most importantly, a meaningfu assessment of Rhode Island's overall economic performance must be based on a broadly based set of indicators, which is precisely what the Current Conditions Index does. Based on the information provided by the Current Conditions Index, most notably another

\begin{tabular}{|l|r|r|}
\hline \multicolumn{2}{|c|}{ CCI I ndicators - \% Change } \\
\hline Government Employment & -1.0 & \\
\hline US Consumer Sentiment & -3.3 & \\
\hline Single-Unit Permits & -3.1 & \\
\hline Retail Sales & 6.3 & Y \\
\hline Employment Services J obs & -8.8 & \\
\hline Priv. Serv-Prod Employment & -0.1 & \\
\hline Total Manufacturing Hours & 5.1 & Y \\
\hline Manufacturing Wage & 21.1 & Y \\
\hline Labor Force & -1.0 & \\
\hline Benefit Exhaustions & -9.5 & Y \\
\hline New Claims & -4.2 & $Y$ \\
\hline Unemployment Rate (change) & -0.3 & Y \\
\hline \multicolumn{2}{|c|}{ Y = I mproved Value } \\
\hline
\end{tabular}

neutral reading of 50 for February and failure to beat the yearearlier value, I believe it is reasonable to conclude that Rhode Island's economy remains dead in the water. As for this recovery Rhode Island continues to hang on by its finger nails. Speaking of finger nails, forgive me if I keep my fingers crossed as I make this assessment. At any rate, I think (hope?) that this recovery has now reached the two year mark.

\begin{tabular}{|c|c|c|c|c|c|}
\hline & Jan & Feb & Mar & Apr \\
\cline { 2 - 7 } 2011 & 50 & 67 & $67 \uparrow$ & 58 & \\
\cline { 2 - 7 } & 2012 & 58 & 50 & & \\
\hline
\end{tabular}

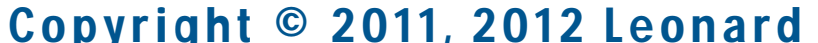

How, then, did the $\mathrm{CCl}$ indicators perform in February? Let's begin with the bright spots. Retail Sales improved for the sixth consecutive month $(+6.3 \%)$, in spite of a 3.3 percent decline in US Consumer Sentiment, which kept its downtrend intact. Rhode Island's manufacturing sector once again showed significant strength, as Total Manufacturing Hours surged by 5.1 percent, based on greater employment and a longer-than-40 hour workweek. Based on such a long workweek (the fifth highest since 2000), the Manufacturing Wage jumped by 21.1 percent. Benefit Exhaustions, a measure of long-term unemployment, fell again, by 9.5 percent. At the other end of the jobless spectrum, New Claims, a leading labor market indicator that includes layoffs, registered a welcome decline of 4.2 percent, only its third improvement in the last eight months. Finally, the Unemployment Rate for February was lower than a year ago, but higher than in the prior month. The fact that the Labor Force fell once again largely negates whatever positive inferences might be made about the year-over-year decline in the jobless rate.

Single-Unit Permits, which tracks new home construction, the most volatile of the $\mathrm{CCl}$ indicators, fell slightly by 3.3 percent in February, in spite of very warm weather. Employment Service Jobs, a leading labor market indicator that includes "temps," fell an eleventh time $(-8.8 \%)$, but it had a very difficult comp from last February. Private Service-Producing Employment declined for its fourth consecutive month, although by only 0.1 percent. Finally, Government Employment fell by 1.0 percent, ironically a moderating rate of decline.

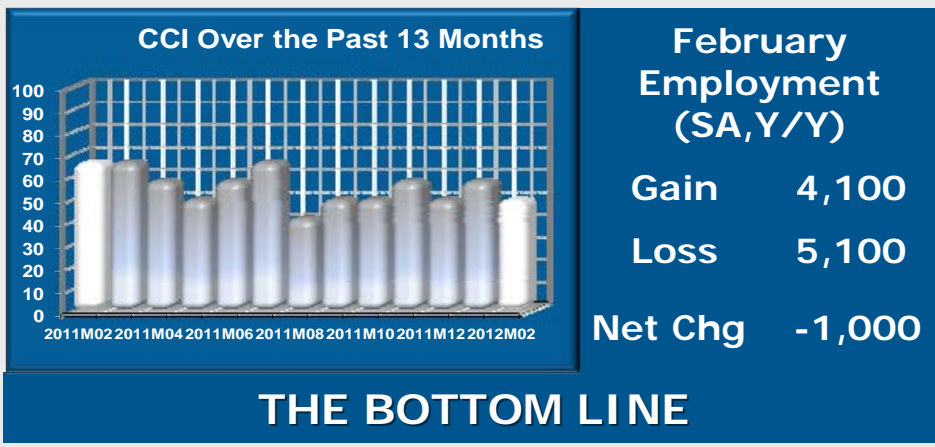

Rhode Island's economy remains at a virtual standstill, which is unfortunate since this slowdown has coincided with an accelerating pace of national economic activity. At this point, I can no longer rule out the possibility that Rhode Island has entered into the earliest stages of a double-dip recession. I still believe that we are still in a recovery, but barely. So, our state's economy continues to move in the wrong direction and many of our cities and towns are on the brink of bankruptcy. Will our leaders ever realize that this is a crisis?

\begin{tabular}{|c|c|c|c|c|c|c|c|}
\hline May & J un & J ul & Aug & Sep & Oct & Nov & Dec \\
\hline 50 & 58 & $67 \uparrow$ & 42 & 50 & 50 & 58 & 50 \\
\hline & & & & & & &
\end{tabular}

